\title{
ПРОГРАММНО-ЦЕЛЕВОЕ ПЛАНИРОВАНИЕ И ЕГО ОСОБЕННОСТИ В ТУРИЗМЕ
}

\begin{abstract}
Фролова Татьяна Викторовна, магистрант Мининского университета

Крайнова Ольга Сергеевна, канд. экон. наук, дои., зав. кафедрой туризма филиал ЧОУВО «Московский университет им. С.Ю.Витте» в г.Нижнем Новгороде, г. Нижний Новгород
\end{abstract}

Аннотация. В статье рассматривается практика применения программно-целевого планирования в индустрии туризма и гостеприимства. Востребованность такого подхода для развития туризма в Российской Федерации обусловлена его возрастающей ролью в экономике страны по показателю валового национального дохода.

Ключевые слова: программно-целевое планирование, программноцелевой подход, программно-целевой метод, комплексная целевая программа, принципы программно-целевого планирования, структура целевых программ развития туризма.

Туризм, являясь выгодной отраслью экономики, может стать при соответствующих условиях важнейшей статьей валового национального дохода России. Для достижения положительного баланса между въездным и выездным туризмом, необходимо всячески поддерживать и развивать внутренний туризм с тем, чтобы деньги тратились внутри страны, а не за ее пределами. Хорошо спланированная политика по развитию и программноцелевое планирование национального туризма приведет в конечном итоге к выгоде для страны. 
Программно-целевое планирование - это системное понятие, состоящее из таких элементов, как программно-целевой подход, программно-целевой метод, комплексная целевая программа.

Программно-целевое планирование как метод управления экономическим и социальным развитием страны (региона, отрасли) применяет инструменты разработки и осуществления специфических плановых документов (комплексных целевых программ) [7].

Программно-целевое планирование логически построено по схеме: «цели - способы - средства», которое органично сочетает пути достижения, инструменты достижения цели и их средства. Программно-целевой метод определяет приемы и способы разработки программ и отражает последовательность принятия программных решений во времени и пространстве. Особенностью этого метода является составление конкретной программы достижения желаемых результатов.

Основным достоинством программно-целевого метода в современных условиях является концентрация ресурсов на реализацию взаимосвязанных мероприятий, возможность контроля за их расходованием, корректировки и стимулирования их эффективного использования [6].

Методология программно-целевого планирования определяется такими принципами, как:

- $\quad$ комплексность (отражение в программе мероприятий и заданий по цепочке их взаимосвязей, а также по исполнителям независимо от их отраслевой или организационно-правовой принадлежности);

- целенаправленность (обеспечение приоритета цели, определяемой в виде конечного результата, над ресурсами);

- $\quad$ системность (единство целей и ресурсов).

Эти основополагающие принципы разработки программ определяют основные направления использования программно-целевого подхода для эффективного решения проблем в социально-экономическом развитии страны или региона. 
В зависимости от целей, принадлежности, способа действий, времени, масштабности, роли в управлении существует множество целевых программ, поэтому их можно упорядочить и выделить специфические черты методов разработки и управления реализацией разных видов программ [5, с.60].

Таблица 1 - Основные отечественные подходы к планированию и составлению программ развития туризма [5, с.61]

\begin{tabular}{|c|c|c|}
\hline Подход & Основа & $\begin{array}{c}\text { Краткая характеристика } \\
\text { подхода }\end{array}$ \\
\hline Ресурсно-географический & Туристский потенциал & $\begin{array}{l}\text { Сбор и систематизация } \\
\text { данных о туристском } \\
\text { потенциале региона. Оценка } \\
\text { туристских ресурсов по } \\
\text { доступности, безопасности, } \\
\text { аттрактивности и т.д., } \\
\text { дифференцированная для } \\
\text { различных форм и видов } \\
\text { туризма }\end{array}$ \\
\hline Маркетинго-аналитический & Спрос и предложение & $\begin{array}{l}\text { Определение места региона } \\
\text { на отечественном и } \\
\text { международном туристских } \\
\text { рынках. Определение } \\
\text { приоритетов туристского } \\
\text { развития. Оценка } \\
\text { существующего и } \\
\text { перспективного туристского } \\
\text { предложения региона на } \\
\text { основе потребностей и } \\
\text { спроса, расходов туристов и } \\
\text { пр. }\end{array}$ \\
\hline Социально-экономический & $\begin{array}{l}\text { Социально-экономическое } \\
\text { развитие региона }\end{array}$ & $\begin{array}{l}\text { Систематизация и оценка } \\
\text { вариантов развития туризма } \\
\text { в регионе по их } \\
\text { эффективности. Оценка } \\
\text { влияния развития туризма } \\
\text { на регион }\end{array}$ \\
\hline Политико-управленческий & $\begin{array}{l}\text { Организационно- } \\
\text { управленческая структура и } \\
\text { законодательство }\end{array}$ & $\begin{array}{l}\text { Выбор наиболее } \\
\text { эффективных вариантов } \\
\text { развития туризма. } \\
\text { Модификация } \\
\text { законодательной базы. } \\
\text { Совершенствование } \\
\text { управленческой структуры в } \\
\text { регионе }\end{array}$ \\
\hline Проектный & Региональные проекты & $\begin{array}{l}\text { Выработка конкретных } \\
\text { территориально- } \\
\text { планировочных решений в } \\
\text { рамках инвестиционных } \\
\text { проектов }\end{array}$ \\
\hline
\end{tabular}


Структура целевых программ развития туризма в настоящее время в Российской Федерации выглядит так:

- Федеральные целевые программы.

- $\quad$ Региональные целевые программы.

- Муниципальные целевые программы.

Рассмотрим в данной последовательности целевые программы, регулирующие развитие туризма в Нижегородской области [6].

Федеральная целевая программа «Развитие внутреннего и въездного туризма в Российской Федерации (2011 - 2018 годы)» [1]. Целью данной программы является повышение конкурентоспособности российского туристского рынка, удовлетворяющего потребности российских и иностранных граждан в качественных туристских услугах.

Областная целевая программа «Развитие внутреннего и въездного туризма в Нижегородской области в 2012-2016 годах» [3]. Актуальность разработки и принятия данной программы обусловлена необходимостью продолжения комплекса мероприятий по формированию в области конкурентоспособной туристской индустрии, а также достижения целевых значений индикаторов оценки реализации Стратегии развития Нижегородской области до 2020 года [2]. В соответствии со Стратегией отрасль «туризм» является одним из приоритетных и перспективных направлений социально-экономического развития региона: туризм отнесен ко второй группе отраслевых приоритетов и входит в число базовых секторов экономики Нижегородской области. Целевая программа является базовым документом подготовки туристской инфраструктуры региона (в первую очередь гостиничного сектора и сферы общественного питания) к проведению в г.Нижнем Новгороде игр Чемпионата мира по футболу 2018 года [3].

Муниципальная программа «Развитие туризма на территории города Нижнего Новгорода в 2012-2016 годах» [4], основная цель которой - 
повышение конкурентоспособности туристского рынка города Нижнего Новгорода, удовлетворяющего потребности российских и иностранных граждан в качественных туристских услугах.

Успешное развитие туристической отрасли в Нижегородской области без государственной поддержки невозможно. С целью создания высокоэффективных и конкурентоспособных туристических комплексов, обеспечивающих возможности для удовлетворения потребностей российских и иностранных граждан в туристских услугах власть Нижегородской области создает благоприятные условия для развития туризма и оказывает государственную поддержку субъектам туриндустрии как в материальной, так и нематериальной формах. Анализ целевых программ регионов России показывает, что при разных вариантах названий программ основные цели и ожидаемые результаты весьма схожи и основаны на параметрах федеральной целевой программы. Так, практически в каждом регионе намечается создание современной туристской индустрии, увеличение налоговых поступлений в бюджет, рост рабочих мест, приток инвестиций и др.

Однако, не умоляя необходимости применения в туристской индустрии системной политики на основе системного или программного метода, следует отметить, что эффективная ее реализация возможна только при условии соблюдения принципа целевого расходования средств [7].

\section{Список литературы}

1. Федеральная целевая программа «Развитие внутреннего и въездного туризма в Российской Федерации (2011 - 2018 годы)», утвержденная постановлением Правительства РФ от 2 августа 2011 г. № 644/ Правовой сервер «Консультант Плюс» / [Электронный ресурс] // URL: www.consultant.ru (дата обращения: 18.04.2015).

2. Стратегия развития Нижегородской области до 2020 года, утвержденная постановлением Правительства Нижегородской области от 17 апреля 
2006 года № 127/ Правовой сервер «Кодекс» / [Электронный ресурс] // URL: http://www.kodeks.ru/(дата обращения: 18.04.2015).

3. Областная целевая программа «Развитие внутреннего и въездного туризма в Нижегородской области в 2012-2016 годах», утвержденная постановлением Правительства Нижегородской области от 4 октября 2011 года № 797/ Правовой сервер «Консультант Плюс» / [Электронный pecypc] // URL: www.consultant.ru/ (дата обращения: 18.04.2015).

4. Муниципальная программа «Развитие туризма на территории города Нижнего Новгорода в 2012-2016 годах», утвержденная постановлением администрации города Нижнего Новгорода от 08 июня 2012 года № 2290/ Сайт администрации города Нижнего Новгорода/официальные документы / [Электронный pecypc]/ // URL: http://www.admgor.nnov.ru/upload/getODA/depdoc93464.html_ (дата обращения: 18.04.2015).

5. Боголюбова, С.А. Планирование и развитие туризма [Текст] / С.А. Боголюбова.- СПб.: СПбГИЭУ, 2009. - 100 с.

6. Крайнова О.С., Лебедева Т.Е. Особенности государственной поддержки развития внутреннего и въездного туризма: опыт Нижегородской области / Научное обозрение. 2014. № 7-2. С.668-670.

7. Крайнова О.С., Лебедева Т.Е. Разработка и реализация целевых программ развития внутреннего и въездного туризма в Нижегородской области: потенциал для формирования конкурентоспособной туристской индустрии региона. Вестник Национальной академии туризма. 2014. №3 (31). C.37-40. 